\title{
The Erasure Of A Mad And An Infamous Mother In Jean Rhys's Wide Sargasso Sea
}

\author{
Mirza Muhammad Zubair Baig \\ Department of Humanities \\ COMSATS Institute of Information Technology, Lahore Campus
}

\begin{abstract}
The character of Bertha Mason has been stereotyped as a "madwoman in the attic" in Charlotte Bronte's novel "Jane Eyre (1847)." Jean Rhys in her novel "Wide Sargasso Sea (1966)," has tried to re-inscribe her character as Antoinette by analyzing how the imperialist and patriarchal forces led a woman from the wide world of Sargasso Sea to the attic of Thornfield Hall England. My contention to this corrective process of rewriting as rerighting is that, in an effort to authenticate Antoinette's character, this writing has othered Annette, Antoinette's mother, and has, in return, created another madwoman who has been left unattended in the plot that should have written back to the canon instead of furthering canonical images.

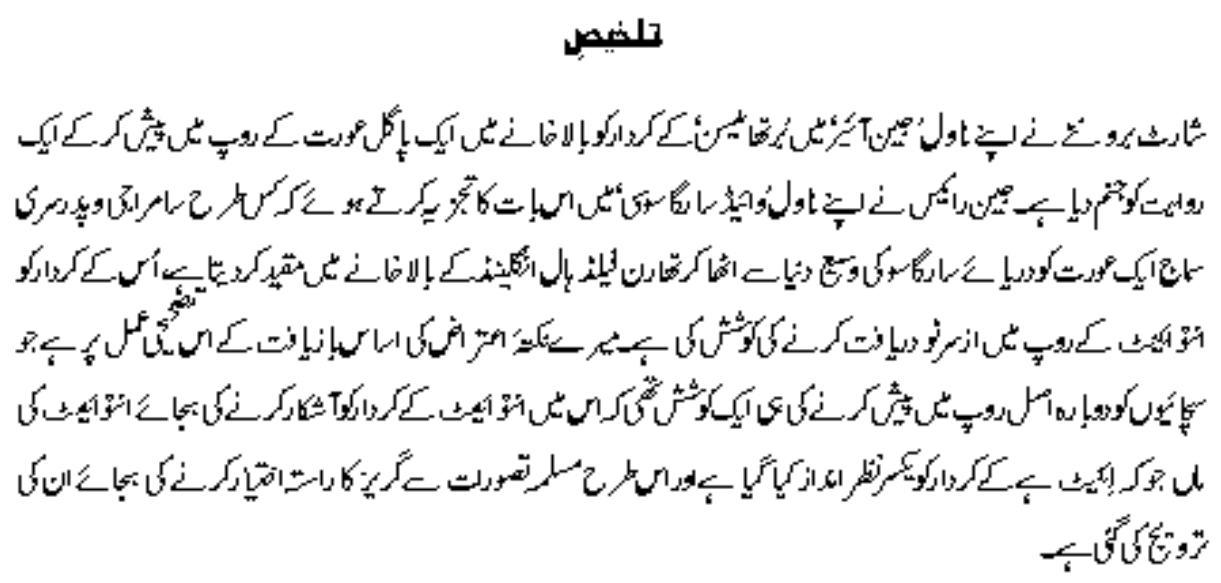

Key Words: Canon, Rewriting, Patriarchy, Erasure

\section{Introduction}

This essay is based on the researcher's unpublished doctoral research that studies how far the rewritings of the Western canonical texts could "re-right" the absences stereotyped in the patriarchal and colonial cultures. The normative structures of canonicity mispresent and erase the objectified other to their advantage. These absences and erasures have been studied with reference to the feminist/postcolonial parallel themes of voice, identity and 
representation with the view that the imperial and patriarchal Other standardize the "lesser beings" (Baig, 2012).

Wide Sargasso Sea (1966) is "bildungsroman" of a Creole girl, Antoinette Cosway and re-presentation of Bertha Mason of Charlotte Bronte's Jane Eyre (1847). Her life from a child to girlhood and from girlhood to womanhood in Jamaica has been contextualized by the experiences of slavery, racial discrimination and crumbling of planter class and Estates underscored by the Emancipation Act. As a child, Antoinette was ignored by her mother. According to her childhood friend, Tia, her mother was shy of her Creole origin.

Edward Fairfax Rochester in Charlotte Bronte's Jane Eyre traces Miss Mason's matrilineage: "Bertha Mason is mad; and she came of a mad family; idiots and maniacs through three generations" (p:315). Her mother Annette was a French Creole from a French colony, Dominica. The Dominican part of her life is inaccessible in the story. After the death of her first husband Alexander Cosway, a slave owner, she manages the run-down plantation on Coulibri Estate with a little help from the untrustworthy slaves. In view of the Emancipation Act and English "promise" for emancipation, the slaves start the rising up. She marries Mr. Mason, an Englishman, who momentarily gives her economic relief but, later on, turns a deaf ear to her. She remains unheard. The dissident slaves burn the Coulibri Estate and her invalid son Pierre also dies. His death symbolizes end of Cosway line. She is much grieved and fights with her husband over it. He hands her over to a black couple for caretaking. The man molests her at his will along with other men and no one stops them. She remains left-out and bereaved, unable to defend herself or attend to her daughter.

\section{Theoretical Perspective: Spivak vs. Bhabha}

The novel Wide Sargasso Sea is set in post-Emancipation ${ }^{1}$ Act (1833) Jamaican society. The novel opens with the question of Emancipation Act, resentment of the locals over the post- Emancipation Act situation, decaying Estates, absence of masters and fruits of freedom-making Jamaican life a troubled life where the women and the Creoles suffered the most. The reason these colonized have been sidelined and missed can be better understood by what Spivak says:

Both as object of colonialist historiography and as subject of insurgency, the ideological construction of gender keeps the male dominant. If, in the context of colonial production, the subaltern has no history and cannot speak, the subaltern female is even more deeply in shadow. (Spivak, 1988, p. 287)

Spivak is talking specifically about women. However, in colonial system, the signification keeps the colonizer dominant. The patriarchal system further others the subject women and pushes them "deeply in shadow" while representing them. In case of 
current study, Annette takes exception to Spivak's claim as she remains in the "shadow" of her daughter Antoinette's narration, instead, in Wide Sargasso Sea.

In case of rewriting, nevertheless, in an attempt to restore the "mad woman" in Jane Eyre to justice, her mother has been relapsed into anonymity. However, I have also noticed that this female agency has been eclipsed by the "phallocentric repression" (Friedman, 1992, p. 64) even in the rewriting. Annette stands up to Mr Mason but she faces colonial and patriarchal oppression.

From Bhabha's perspective, stereotype has been interpreted as "fixity" (1994b , p. 66) in colonial or patriarchal writings, which is challenged by the voice and interruption of the stereotyped from within the text. It is "an unchanging order as well as disorder, degeneracy and daemonic repetition" (1994b, p. 66). The repetition of the stereotyped challenges the previous demonic image of the colonized. In case of the present text, the "difference" in her mis-presentation and re-presentation gives Bertha Mason an identity of Antoinette of Jamaica. Rhys has made Bertha Mason "not quite" the same as claimed by Bhabha (1994a, p. 86). She has a life prior to her imprisonment in Thornfield Hall. This difference in re-presentation "menace"(s) (1994a, p. 86) Bertha Mason's stereotyped representation and challenges colonial authority. The rewritten characters problematize the stereotypical understandings of the reader.

Contextualizing Bhabha's contribution to the concept of stereotype, Huddart (2006) elaborates:

Stereotypes function to enable colonial authority [. . .] there is a simultaneous anxiety built into the operations of colonial knowledge [. . .] that anxiety troubles the source of colonial authority. This anxiety is necessary for the production of new stereotypes, but is also the space for counter-knowledge and strategies of resistance and contestation. (p. 37)

According to Huddart (2006), stereotypes are both source of "colonial authority" and "resistance." The difference in the presentation of stereotyped images causes "anxiety" to the colonial hegemony. Where to the colonial authority the new stereotypes should correlate to the old fixation of the othered for the continuation of their power, the "difference" in their re-production in re-writing is a challenge to the pre-structures of colonial and patriarchal authority. Here, we find that, in case of this novel, the image of "mad woman" is re-presented both for mother-daughter, Annette-Antoinette. We again find Mr. Rochester calling Antoinette, daughter of an "infamous mother." However, the biographical and historical context of mother-daughter makes their "stereotyped" representation "deferred" as Derrida calls so, and Homi K. Bhabha considers them "not quite the same." 


\section{The Infamous Mother and Black Righteousness}

Bhabha is of the view that "discriminatory stereotypes should be identified, and so replaced with authentic images" (1994b, p. 121). Here the excavation of "infamous" mother's story is also an attempt to locate her "authentic" image. Annette, Antoinette's mother, is the alleged "infamous mother" in Jane Eyre. Antoinette fails to situate her mother, "a Martinique girl" (17), and herself in the racial Jamaican society:

Perhaps she had to hope every time she passed a looking glass. [ . . . ] She still rode about every morning not caring that the black people stood about in groups to jeer at her, especially after her riding clothes grew shabby (they notice clothes, they know about money). [ . . . ] I saw her horse lying down [ . . ] dead. (Rhys, Wide Sargasso Sea, p. 18)

"Had to" suggests that she had no other options but to face the hard life after the death of her husband. The black "people" have been mis-presented as sadist when the narrator records them jeering at a marooned lady "in groups." The narrator relates their boldness to deficiency of money in the Coulibri Estate presently owned by Annette. Her "shabby" clothes, "not caring" attitude and going out not only reveal her poor economy but also her will to live on. However, someone from the natives or servants poisons her horse to break her up but this attempt also fails. Her gazing at looking glass gave her "hope." Her husband Alexander Cosway was a drunkard who could not withstand the deteriorating plantation caused by "emancipation" and resultantly died. She took the onerous task of earning herself instead of relying on the forced labor. She sank into poverty after her husband's death. Black people's jeering at her mother's "shabby clothes" is a kind of revenge for their slavery. This emotional reaction can be a way to compensate for the (colonial) times when they were jeered at. Her "shabby clothes" also reflect on their sufferings. Someone even poisoned her horse which she would use for her earning. The poisoned dead horse left them "marooned" with the existentialist question: "now what will become of us?" After Cosway, Annette earns livelihood for the inmates of the deteriorating Coulibri Estate but her helper (an animal), the horse, is poisoned in an effort to limit her options in life. She was to depend on the old servants like Godfrey who were not dependable any longer when they had their own grievances and understanding of post-Emancipation life. Their life was in the phase of metamorphosis, changing from ages of slavery to hope of an emancipated life. Their loyalties and sympathies were more with the natives than the planter class. Godfrey is regarded "old hypocrite," by Annette. As an individual from the relics of the feudal past, he reassures perturbed Annette, "The Lord make no distinction between black and white, black and white the same for Him. Rest yourself in peace for the righteous are not forsaken" (Rhys, p. 18).

The "righteous" are not "forsaken" "is a biblical reference used by Godfrey. The meaning of "righteous" has been deferred as every character thinks that he/she is right. Truth and reality 
are slippery in the text. The people believing in the Lord know that He does not make any distinction among the human beings on the basis of the color of their skin, but the racial and ethnic conflicts within the Jamaican society are quite a paradox to the teachings of Holy Bible. Henceforth, "peace" remains elusive for Annette throughout the text.

This issue of identity refers to what Bhabha calls "the problematic of seeing/being seen" (1994b, p. 76). In the gaze of the slaves, they are righteous instead of the claimant rulers. The blacks and whites are not "same" in the society but binaries. The identity and identification of the "righteous" remains debatable throughout the novel. Annette suspects Godfrey for being party to the poisoning the horse, the bread-winner of the family. She is left with no one to depend on or believe. The blacks were wronged in the past; now the Whites and Creoles are facing the consequences and especially the women are at greater risk. Godfrey, a type for newly "freed" slaves, defines re-adjusted masterslave relationship. However, Godfrey's alleged "hypocrisy" is exposed when he is overheard by the narrator, Antoinette, "Godfrey said that we were not righteous. One day when he was drunk he told me that we were all damned and no use praying" (Rhys, p. 33).

This brings into focus the enmity between the haves and haves-not of which Annette is convinced but Mr. Mason, later on, consistently denies and overlooks. Mason's estates in Trinidad, Antigua and Jamaica explain much about wide spread slavery in the Caribbean islands. We come to know that Mr. Mason is a polygamist. He has a son by his first marriage, Richard, who is at school in Barbados. Richard's story is untold, remains unattended and we could never find even a hint about his mother. Here in Jamaica, Annette, a "white nigger," and "white cockroach," turns into an object of "enmity" for the natives. The negroes' struggle and concern for their rights, emancipation, identity, voice and representation has been interpreted as "enmity." They were "righteous" and fighting microcosmically for the oppressed and despised humanity. Godfery, the insider of Coulibri Estate, can only speak out in the drunken state that all the inmates of Coulibri Estate were "all damned."

\section{Annette's Physical Charms and Mr. Mason's Ulterior Motives}

One of the gossiping women during the marriage ceremony of Mr. Mason and Annette associates Annette's physical charms with a song, "light as cotton blossom on the something breeze", or is it air? I forget" (Rhys, p. 29). Annette's physical charms are also a kind of wealth. This marriage not only promises Annette to Mason but also the Coulibri Estate and its plantation-a right site to make an investment. "Cotton blossom" again reminds the reader about colonial times and cotton industry. They went to Trinidad for honeymoon, another plantation site. "One of the women gossiping" represents another narrative voice. An "anonymous woman" comments on Mr. Mason's hidden intentions behind marrying Cosway’s widow: 
[... ] he came to make money as they all do. Some of the big estates are going cheap, and one unfortunate's loss is always a clever man's gain. (Rhys, p. 30)

How do you (Mr. Mason) know that I was not harmed?" she said. "We were so poor then," [ . . . ] Do you suppose that they don't know all about your estate in Trinidad? And the Antigua property? (Rhys, p. 32)

Now it had started up again and worse than before, my mother knows but she can't make him believe it. I wish I could tell him that out here is not at all like English people think it is. (Rhys, p. 34)

The English men's coming to colonies was not by any means a holy business. They were looking for the sake of a great career. An "unfortunate's loss" symbolizes the decaying estates like Nelson's rest and the Coulibri referred to in the novel. The text reveals that Mr. Mason is a "clever man" who came to "make money." Marrying a charming lady from the colonies is not a serious business. Marriage proves just a pastime for the money-minting colonizers. This impression is consolidated when the readers find out how Mr. Mason finally commits her wife to a wretched living. It is also to be noted that the native's reason for resentment is English man's "property." The parasitic relationship between the colonizers and the slaves is challenged in their gaze-a phenomenon better understood by Annette and Antoinette but ignored by English man. His expansionist designs ignite and intensify the hatred among the locals.

Annette argues with her new husband Mr. Mason to hand over the Estates to an agent leave Jamaica for England in order to escape the misery of native hatred but to no avail. She is disbelieved, and, in return, is laughed at by her husband. Mr. Mason's argument that she belonged to the family of slave owners is an attempt to make the women folk party to the crimes committed by their men. She had never been a slave-owner. She bore the consequences of what her male-counterparts did. She was "molested" and "harmed" mentally and financially. She faced the "hatred" of local community and the daily grind of manual jobs in order to eke out livelihood for the poor and economically "worst." When she wed Mr. Mason, a slave-owner who amassed wealth at the cost of exploitation of Caribbean fields and negroes, she was stigmatized by the newly emancipated negroes.

Antoinette appropriates Mr. Mason as "white pappy" (Rhys, p. 33) in order to acknowledge his timely intervention to rescue them from "poverty and misery," which is though momentarily. She experiences "double consciousness" here. She calls her step father "Mr. Mason" in mind but "white pappy" to his face. Mr. Mason's association with the family makes them again an object of hatred, "worse than before" (Rhys, p. 34) for the enslaved section of community. Antoinette interprets the reason for "negroes"/"slaves" revived hatred as:

"You don't keep your promises." (Rhys, p. 34) 
My stepfather talked about a plan to import laborers - coolies he called them - from the East Indies. When Myra had gone out Aunt Cora said, "I shouldn't discuss that if I were you. Myra is listening" [ . . . "Unhappily children do hurt flies," said Aunt Cora. (Rhys, p. 35)

The plan to "import laborers" connects the localized experience of slaves in Jamaica to the outreaching experience of "laborers" from East Indies. It is relevant to note here that the concept of "slaves" is being replaced by that of the "labourers." The clause "If I were you" and the following advice create a marked difference between the patriarchal ignorance and arrogance, and the caring and understanding attitude of the women folk. Aunt Cora quite understands that the newly freed slaves are "unhappy" with their former masters.

English colonial masters are onlookers and outsiders who are not sensitized to the real situation in the Jamaican community. Annette rightfully distrusts Mr. Mason's assurances as the proceedings of the novel bear out. Generally, neither could Jamaican enslaved society get Emancipation at the hands of English planters nor could Annette or Antoinette specifically from their husbands.

After the death of her husband and son, Annette's harder life forces her to retreat into silence. Annette's emotional outbursts are actually the desperate protests against not being heard. As Spivak states in an interview, "the subaltern cannot speak" means that even when the subaltern makes an effort to the death to speak, she is not able to be heard" (MacLean \& Donna, 2005, p. 292). Devadas and Nicholls (2002) also note that:

the "cannot speak" in "the subaltern cannot speak" is gesturing to the impossibility of speech to an audience that refuses to hear and respond to the crying out. It is this incomplete transaction that suppresses the subaltern.[ . . . ] [S]peaking, as a complete transaction, is only possible on the contingency of the reception of the sent message." ( p. 95)

When the natives come to burn the Coulibri Estate, with Annette distraught and traumatized at the death of her son and parrot, Mr. Mason is quite baffled at their unexpected rising:

"There is no reason to be alarmed," my stepfather was saying as I came in. "A handful of drunken negroes." [ . . . ] A horrible noise swelled up, like animals howling, but worse. (Rhys, p. 37)

Annette screams out "Qui est là? Qui est là?", then "Don't touch me. I'll kill you if you touch me. Coward. Hypocrite. I'll kill you." (Rhys, p. 46-7) 
the man lift her up out of the chair and kiss her. I saw his mouth fasten on hers and she went all soft and limp in his arms and he laughed. The woman laughed too, but she was angry. (Rhys, p. 134)

"No reason to be alarmed" reflects Mr. Mason's inability to understand the gravity of the situation. "Drunken negroes," "animals howling" and "horrible noise" bring to mind the colonial stereotyping and essentializing the image of the slaves. "A handful" implicates that as an imperialist, he is too sure of himself. After the death of her son and parrot, she repeats the question who there is for her now. She loses her faith over the English and colonial authority of her "coward" and "hypocrite" husband. Her threat to "kill" is just a transitory spillover of exasperated emotion and a way to protest against patriarchal injustices. Otherwise, she does not actually execute this threat. Mr. Mason's leaving her in the caretaking of a black man and a woman justifies Antoinette's labeling him as "hypocrite" and "coward." Her anger against black man's perpetual sexual assault is a minimal way of resistance against black patriarchy.

The burning of Coulibri Estate alludes to the historical salve rebellions in the Caribbean region. Zacek (2005) notes, "Slave rebellions were a major and constant source of anxiety to planters in the British colonies in the Caribbean throughout the era of slavery" (p. 895). Mr. Mason fails to understand the situation when the negroes come one night to burn down the Coulibri Estate - the emblem of their slavery. The narrative voice of the first part of the novel is partial to the slaves. The natives are depicted in animalistic images. Juang (2005) observes this phenomenon while talking about the experience of Caribbean slavery, "White colonial society often stereotyped slave men as sexually aggressive and portrayed slave women as lascivious" (p. 909). During this episode, while twisting her hands in nervousness and consternation, Annette's wedding ring falls off. It has symbolic significance, and means the end of their married life. After it, their relationship is never reconciled.

Her mother "hated" Mr. Mason who handed her over to a hired coloured man and woman to "look after." He went to Trinidad and almost "forgot" her. But the caretakers molested her as the text witnesses. The black woman's laughing seemingly shows that she is party to her man's crime. However if we contextualize this episode with Annette's former husband's sexual abuse of black slave women, we understand that the black women here are acting as binary to Annette out of the sexual violation faced by the slaves at the hands of the slave owners.

\section{Che Coco: Metonym for Annette}

Annette's Parrot is the only living creature who reminds of and attaches her to Martinique. He mimics in French language, legacy of colonial rule in Martinique. 
Pecking at feet explains that he always remains ready to defend her against any expected danger of physical assault which might look an ineffective effort. It has symbolic significance and emotional support for Annette:

After Mr. Mason clipped his wings he grew very bad tempered, and though he would sit quietly on my mother's shoulder, he darted at everyone who came near her and pecked their feet. (Rhys, p. 41)

His "clipped" wings find an analogy to her situation. He grows "bad tempered" because of Mr. Mason's robbing him off his wings. This incident is symbolic when we compare this clipping in contrast with Mr. Mason's handling of her wife Annette. Like the clipped winged parrot, Mr. Mason detains her by the vows of marriage. He gets full authority over her destiny by default in the absence of some concrete laws formed for her protection. Like him, she remains vulnerable to Mr. Mason's fancies. No one responds to his question "Qui est là ?" but he himself. He, at least, remembers his given name "Che Coco." His voice remains meaningless. In his post clipped wings life, he finds solace by perching on Annette's shoulder. In a way, he has preserved her identity, cultural legacy and home. Mr. Mason lets her parrot die that means an erasure of her emotional, cultural and social self. Later on, we come to know about her emotional and nervous breakdown.

\section{Mother-Daughter Fractured Relation}

Wide Sargasso Sea is more of a female Creole story than finding the reasons of the causes of maternal repudiation and indifference. Her mother was so inextricably caught up in the post-Emancipation events and Jamaican patriarchal system that she failed to $\mathrm{m}$ (other) her daughter according to the demands of the society.

But she pushed me away, not roughly but calmly, coldly, without a word, as if she had decided once and for all that I was useless to her. (Rhys, p. 20)

My mother never asked me where I had been or what I had done. (Rhys, p. 23)

Here "roughly" but "calmly" expresses the internal contradiction in Annette's being. This shows that she fails to mother her "useless" child because of patriarchal and colonial repression and sadism. Her every attempt to escape misery has been equally thwarted by white and black patriarchy. Antoinette mistakes her mother that she was unkind to her "useless" daughter. Annette's inability to mother was aggravated by male "hypocrisy" (in case of Mr. Mason) and her ill son Pierre. The economic challenges of earning in opposition to deteriorating Coulibri Estate and rising slave rebellion was too much for her. 


\section{Christophine defends Annette's Alleged Madness}

Christophine elaborates Annette's post-Coulibri life as life of "madness":

They drive her to it. When she lose her son she lose herself for a while and they shut her away. They tell her she is mad, they act like she is mad. Question, question. But no kind word, no friends, and her husban' he go off, he leave her. [ . . . ] she give up, she care for nothing. That man who is in charge of her he take her whenever he want and his woman talk. That man, and others. Then they have her. Ah there is no God. (Rhys, p. 157)

Annette has been "driven" to madness while in reality she is not a mad person. She has been "shut away" under the ruse of madness. She also shares how Annette is facing sexual violence at the hands of caretakers and other men. Though excruciating, this obeah practicing woman challenges Christian concept of merciful God. These anonymous men have nowhere been questioned in the text. "Give up" and "caring for none" is a hopeless attitude shown by Annette because of indifferent patriarchy and phallocentric oppressive law. This desperate situation leaves a question which has no answer in the text.

We can compare Annette's imprisonment with Antoinette's. Both have been driven to madness. Though we can find Antoinette's voice and retention of her memory in the third part of the novel, we have no access to Antoinette's voice about the days of her enslavement. Here, we notice that women and men are totally disconnected. Men use them and treat them as objects. The women are made into what they want them to be. They have fragmented tales and representation in the text. We can compare Annette's situation with Antoinette. In daughter's case, she is also driven in a hopeless situation in the detention of Thornfield Hall. It is important to note that patriarchy uses these situations to "break" women up when they cannot send them away "quicker." The white and black patriarchy is using women for their revenge in their effort to dominate. The rape by the black man and his accomplice can be seen from an angle other than patriarchal oppression and repression. Hooks explains that the resistance by blacks has been taken as gendered and male-centric. An understanding emerged that violating the bodies of white women give the dominated black men power over the white men: "It is a story of revenge, rape as the weapon by which black men, the dominated, reverse their circumstance, regain power over white men" (Hooks, 1990, p. 58). Though Annette has been a Martinique girl, however, she has been associated with the slave-owner and white English man in the text. She might have been sexually traumatized because of her former husbands' (Alexander Cosway and Mr. Mason) sins of commission. 


\section{Conclusions}

The character of Annette remains stereotyped as an "infamous mother"in Jean Rhys's novel Wide Sargasso Sea (1966). The imperialist and patriarchal forces of oppression relegated the displaced Martinique girl to the demonic image of a mad infamous mother. The Jamaican part of her life contributes to the corrective process of rewriting as rerighting and authenticate Antoinette's image but the inaccessibility to pre-Jamaican and post- incarceration life makes the narrative altogether oblivious of her faithful representation. Though the selective repetition of this character limits the scope of rewriting yet the "anxiety" in the mind of the writer, reader and the characters makes this infamous mother not just the "same" to use Bhabha's words. Even in rewriting, the narrative has somewhat left her as an "other" yet she is "entirely knowable and visible" (1994b, p. 70-1) viz-a-viz her canonical mis presentation. Bhabha is of the view that "discriminatory stereotypes should be identified, and so replaced with authentic images" (1994b, p. 121). Here, the excavation of "infamous" mother's story is, at least, an attempt to locate her "authentic" image. The reader waits, in anticipation, for narrativized justice and equality in order to claim her authentic image in time, sometime.

\section{End Notes}

${ }^{1}$ Figueredo and Argote-Freyre recall that Emancipation act did not change the situation radically. The whites were in the controlling position and were economically and politically stronger. The blacks still faced discrimination and could find very rare opportunities for their economic development:

In the British Caribbean, for instance, there were 750,000 freed slaves, but there was little they could do with that freedom. [ . . . ] In Jamaica in 1863 , out of a total population of 440,000 , only 1,457 people were eligible voters. Tension and resentment simmered in the Caribbean as a result of these inequalities. (p. 107)

See Figueredo, H. D., \& Argote-Freyre, F. (2008). "Slave rebellions, antislavery movements, and wars of independence (c. 1700-1850)." A brief history of the caribbean. New York: Infobase Publishing.

2 “...I have not seen the righteous forsaken..." See "The Heritage of the Righteous and the Calamity of the Wicked (37:25). Radmacher, E. D., Allen, R. B., \& House, H. W. (2007). Nelson's NKJV study Bible: NKJV, New King James Version. Nashville: T. Nelson, p.855.

3 "Who is there?" <http://translate.google.com.pk/?js=n\&prev=_t\&hl=en\&ie=UTF$8 \&$ layout=2\&eotf $=1 \& \mathrm{sl}=\mathrm{fr} \& \mathrm{tl}=\mathrm{en} \& \mathrm{text}=\mathrm{Qui}+\mathrm{est}+1 \% \mathrm{C} 3 \% \mathrm{~A} 0 \#$ submit $>$ 


\section{References}

Baig, M.M.Z. (2012). Rewritings: A feminist/postcolonial study of absences in western canonical texts, (Unpublished doctoral dissertation), Available from AntiPlagiarism Unit database, National University of Modern Languages, Islamabad.

Bhabha, H. K. (1994a). Of Mimicry and Man: The Ambivalence of Colonial Discourse, The Location of Culture, London and New York: Routledge, pp. 85-92.

Bhabha, H. K. (1994b). Signs Taken for Wonders: Questions of Ambivalence and Authority Under a Tree Outside Delhi, May 1817. The Location of Culture, London: Routledge, pp. 102-122.

Bronte, C. (2003). Jane Eyre. J. C. Oates (Ed.). New York: Bantam.

Devadas, V. \& Nicholls, B. (2002). Postcolonial Interventions: Gayatri Spivak, Three Wise Men and the Native Informant, Critical Horizons 3, pp. 73-101.

Friedman, S.S. (1992). Hysteria, Dreams, and Modernity: A Reading of the Origins of Psychoanalysis in Freud's Early Corpus. In Kevin J. H. Dettmar, (Ed.), Rereading the New: A Backward Glance at Modernism, Ann Arbor: University of Michigan Press, pp. 41-71.

Figueredo, H. D., \& Argote-Freyre, F. (2008). Slave Rebellions, Antislavery Movements, and Wars of Independence (c. 1700-1850). A Brief History of the Caribbean. New York: Infobase Publishing.

Hooks, B. (1990). Yearning: Race, Gender, and Cultural Politics. Boston, MA: South End.

Huddart, D. (2006). Homi K. Bhabha. Abingdon, OXON: Routledge.

Juang, Richard M. (2005). Slave Trade, Atlatic. In W. Kaufman \& H. S. Macpherson (Eds.). Britain and the Americas: Culture, Politics and History, Santa Barbara, CA: ABC-CLIO, pp. 902-913.

MacLean, G. M., \& Donna L. (2005). The Spivak Reader: Selected Works of Gayatri Chakravorty Spivak. New York: Routledge.

Radmacher, E. D., Allen, R. B., House, H. W. \& Thomas Nelson. (2007). Publishers, NKJV Study Bible: New King James Version, Nashville: Thomas Nelson. 
Rhys, J. (1982). Wide Sargasso Sea, New York: W.W. Norton.

Spivak, G.C. (1988). Can the Subaltern Speak? In C. Nelson \& L. Grossberg, (Eds.), Marxism and the Interpretation of Culture, Urbana: University of Illinois Press, pp. 271-313.

Zacek, N. (2005). Slave Rebellions, Caribbean. In W. Kaufman \& H. S. Macpherson (Eds.), Britain and the Americas: Culture, politics and History, Santa Barbara, CA: ABC-CLIO, pp. 895-898.

Dr. Mirza Muhammad Zubair Baig is Assistant Professor in the Department of Humanities, COMSATS Institute of Information Technology. 